Medycyna personalizowana jest najczęściej przedstawiana jako „odpowiednia terapia dla odpowiedniej osoby we właściwym czasie". W celu lepszej organizacji systemów informacji medycznej i stworzenia płaszczyzny dla medycyny personalizowanej m.in. Stany Zjednoczone i Unia Europejska wprowadzity w życie szereg przepisów dotyczących systemu Elektronicznego Rekordu Pacjenta (EHR). Ogromny wzrost liczby medycznych baz danych i repozytoriów medycznych, w szczególności w dziedzinie onkologii, daje ogromne możliwości wykorzystania ich do eksploracji danych dla odkrywania wiedzy. Najnowsze wysoko wydajne technologie, które sondują i zagłębiają się w tajniki mechanizmów nowotworowych, są obiecujące pod względem wczesnej i bardziej specyficznej diagnostyki, włączając $w$ to informację dotyczącą guza pierwotnego, stopnia zaawansowania choroby, jak również predykcyjnej wartości leczenia. Ponadto szerokie wykorzystanie eksploracji danych w odniesieniu do informacji genetycznych, klinicznych i czynników fizycznych w istotny sposób może się przyczynić zarówno do zindywidualizowania leczenia dla konkretnego pacjenta, jak i obniżyć koszty samej terapii onkologicznej.

Słowa kluczowe: medycyna personalizowana, eksploracja danych, elektroniczny rekord pacjenta, onkologia molekularna.

\section{Personalized medicine in oncology: vision or realistic concept?}

\author{
Medycyna personalizowana w onkologii - wizja czy realna koncepcja?
}

\section{Remigiusz Lewandowski ${ }^{1}$, Krzysztof Roszkowski ${ }^{2}$ Marzena Anna Lewandowska ${ }^{2,3}$}

${ }^{1}$ Center for Interdisciplinary Research in Pediatric Critical Illness and Injury, Children's Memorial Hospital, Northwestern University Feinberg School of Medicine, Chicago IL, USA

${ }^{2}$ Centrum Onkologii im. prof. F. Łukaszczyka, Bydgoszcz, Polska

${ }^{3}$ Cell and Molecular Biology, Feinberg School of Medicine, Northwestern University, Chicago, IL, USA

\section{Wstęp}

Określenie personalized medicine tradycyjnie odnosi się do systemu zdrowia, który jest „uszyty na miarę” dla pacjenta oraz często do specjalistycznego leczenia opartego na informacji genetycznej pacjenta.

Medycyna personalizowana jest najczęściej przedstawiana jako „odpowiednia terapia dla odpowiedniej osoby we właściwym czasie" [1]. Każdy lekarz już dziś stosuje podstawy medycyny personalizowanej na co dzień, np.: dozując odpowiednią dawkę leku dla danego pacjenta, zmieniając rodzaj leku na bardziej efektywny czy też zlecając odpowiednie testy diagnostyczne. To tradycyjne podejście bazuje na związku pomiędzy chorobą a reakcją pacjenta na leczenie. Wiadomo, że poszczególni chorzy mogą reagować inaczej na te same leki, np. 75\% pacjentów reaguje w inny sposób na leki onkologiczne [2].

Najnowsze technologie, które sondują i zagłębiają się w tajniki mechanizmów nowotworowych, są obiecujące pod względem wczesnej i bardziej specyficznej diagnostyki, włączając w to informację dotyczącą guza pierwotnego, stopnia zaawansowania choroby, jak również predykcyjnej wartości leczenia.

W prezentowanym artykule przeglądowym skupimy się na wykorzystaniu najnowszych wysoko wydajnych technologii molekularnych (,high-through" technology) oraz koncepcji eksploracji danych w celu określenia indywidualnej profilaktyki, diagnozy, leczenia i monitorowania pacjenta w postępowaniu onkologicznym.

\section{Informatyzacja i eksploracja danych medycznych na świecie i w Polsce}

Powszechna digitalizacja i informatyzacja w służbie zdrowia prowadzi do gromadzenia różnorodnych danych z wielu obszarów. Informacje te dotyczą m.in. demografii, danych laboratoryjnych, administracyjnych czy też monitoringu z urządzeń medycznych [3]. Informacje zgromadzone w bazach danych czy też w repozytoriach danych medycznych przy użyciu podstawowych metod nie zawsze dają odpowiedź na stawiane pytania. Celowe staje się zatem zastosowanie metod eksploracji czy też drążenia danych (data-mining) w celu dostrzeżenia ukrytych zależności, bez z góry ustalonych hipotez [4]. W analitycznej metodzie eksploracji danych można wykorzystywać metody sztucznej inteligencji, analizę skupień czy wizualizację danych [3]. Metody sztucznej inteligencji wykorzystano m.in. we wsparciu decyzji medycznych w diagnostyce i prognostyce w onkologii [5]. Tym samym zastosowanie technik eksploracji danych w celu odkrywania wiedzy z dostępnych baz danych może być krokiem w kierunku bardziej zindywidualizowanej terapii. 
Personalized medicine is often described as "the right treatment for the right person at the right time". In order to better organize medical information systems and create a platform for personalized medicine the United States and the European Union have put into effect several regulations regarding the Electronic Health Record (EHR) system. A dramatic growth of the number of medical databases and medical data repositories, especially in the field of oncology, offers a great opportunity to apply data-mining for knowledge discovery. New high-throughput technologies that enable the exploration of complex oncological mechanisms appear promising in terms of earlier and more specific diagnostics, including data associated with the primary tumor site, the stage of disease, as well as treatment predictions. In addition, a broad application of data-mining as regards genetic and clinical information, and physical factors can substantially enhance individual therapy for each patient and potentially reduce the cost of cancer therapy.

Key words: personalized medicine, datamining, Electronic Health Record, molecular oncology.
Rozwój informatyki medycznej ma bezpośredni związek z rozwojem medycyny personalizowanej, która jest w pewnym stopniu uznawana za nową wizję opieki medycznej na świecie. Dlatego też w minionym dziesięcioleciu władze Stanów Zjednoczonych podjęły działania mające na celu stworzenie dla każdego obywatela do 2014 r. pełnej dostępności do Elektronicznego Rekordu Pacjenta (Electronic Health Record - EHR) [1], czyli do indywidualnej elektronicznej dokumentacji medycznej. Obecnie 68\% szpitali w Stanach Zjednoczonych wykorzystuje EHR, w tym 11\% szpitali w pełni wdrożyło go w swoich placówkach [6]. Przyjmuje się, że dalszy rozwój EHR przyczyni się do znacznego obniżenia kosztów opieki medycznej, zmniejszenia czasu leczenia, a także poprawienia komfortu samej kuracji.

Obecnie wiele instytucji w Stanach Zjednoczonych stara się wykorzystać EHR dla bardziej spersonalizowanej terapii oraz badań. Przykładem może być Harvard Medical School, gdzie prowadzi się prace nad zintegrowanym systemem EHR dla wspomagania decyzji klinicznych przy zastosowaniu narzędzi do interpretacji testów genetycznych. Dzięki temu możliwe będzie znalezienie nowych korelacji między informacją genetyczną, chorobami a odpowiedzią na leczenie. System zostanie wdrożony w Massachusetts General Hospital w celu gromadzenia informacji genetycznej dla pacjentów onkologicznych, aby zaoferować standard leczenia zbliżony do kanonów medycyny spersonalizowanej [1]. Innym przykładem jest szpital Children's Memorial Hospital w Chicago wykorzystujący platformę Xenobase do eksploracji danych pacjentów, m.in. do badań nad przetaczaniem macierzystych komórek hematopoetycznych (R. Lewandowski, dane niepublikowane).

Także Komisja Europejska poprzez Dyrekcję Generalną do spraw Społeczeństwa Informacyjnego i Mediów zabiega o wdrożenie systemu EHR we wszystkich krajach członkowskich Unii Europejskiej. W tym celu w 2002 r. został powołany European Institute for Health Records (EuroRec), organizacja o charakterze non profit. EuroRec współpracuje poprzez swoje krajowe niezależne centra (ProRec) [7] z organizacjami służby zdrowia, firmami czy administracją krajową. Celem tej organizacji jest wspieranie wprowadzania EHR na poziomie europejskim [8]. Estonia jako pierwszy kraj na świecie wdrożyła i w pełni udostępniła rekordy swoim obywatelom [9]. Takie kraje jak Wielka Brytania [10], Czechy, Dania, Hiszpania, Niemcy czy Finlandia [11] również prowadzą bardzo zaawansowane prace nad tym projektem.

W Polsce na podstawie rządowego projektu informatyzacji publicznej służby zdrowia „e-Zdrowie Polska 2009-2015” planowane jest wdrożenie Systemu Informacji Medycznej (SIM), czyli stworzenie centralnych baz danych i rejestrów medycznych oraz zwiększenie dostępności do informacji w opiece medycznej dla pacjentów [12].

\section{Data-mining w onkologii}

Na rycinie 1. przedstawiono zastosowanie data-miningu, zwanego drążeniem bądź eksploracją danych w medycynie personalizowanej. Często stosowanymi technikami eksploracji danych w onkologii są drzewa decyzyjne, sieci neuronowe, analiza skupień, sieć Kohonena, analiza głównych składowych czy skalowanie wielowymiarowe $[13,14]$. Czynniki molekularne (genomika, epigenetyka, transkryptomika, proteomika), czynniki kliniczne (dane demograficzne, histologia, data i czas leczenia, metody dotychczasowego leczenia, stadium choroby) i czynniki fizyczne (fizyczne parametry radioterapii, chemioterapii, diagnostyka obrazowa) są zbierane w zintegrowanym Systemie Informacji Medycznej (SIM) lub jako EHR. Bazując na informacji dotyczącej pacjenta z HER/SIM, poprzez eksplorację danych, lekarz otrzyma zindywidualizowaną informację ułatwiającą dokładniejszą diagnozę, leczenie i monitorowanie choroby.

Rozwój wysoko wydajnych technologii (high-throughput technology) służących do poznania genomu, transkryptomu czy proteomu umożliwił analizę ludzkiego DNA, RNA czy białek, a tym samym przyczynił się do zidentyfikowania nowych zmian genetycznych i epigenetycznych w odniesieniu 
do różnych chorób [15]. Dogłębna analiza bioinformatyczna połączona z data-miningiem i interpretacją wyników, identyfikacja czynników genetycznych i rozwój leków bazujących na różnorodności genetycznej [15] wpłynie zarówno na dalszy rozwój diagnostyki, prognostyki, jak i skuteczność samej terapii [16]. Obecnie w nowoczesnych badaniach onkologicznych stosowanie wysoko wydajnych technik (high-throughput) stało się faktem, a wiele projektów opiera się na eksploracji tych informacji. Integracja danych onkogenomicznych zgromadzonych z różnorodnych źródeł z projektami o dużej skali (np. The Cancer Genome Atlas oraz International Cancer Genome Consortium) umożliwi wizualizację zmian w genomie istotnych dla kancerogenezy [17].

Dane zgromadzone w medycznych bazach danych i ich eksploracja może się przyczynić do znalezienia korelacji pomiędzy krytycznym zbiorem mutacji, które definiują typ nowotworu, a określonym najbardziej efektywnym leczeniem [18]. Jednym z takich przykładów są testy diagnostyczne określające np. polimorfizm pojedynczego nukleotydu (single nucleotide polymorphism - SNP). Wyniki takich testów genetycznych mogą się przyczynić do zmniejszenia niepożądanych efektów związanych z terapią onkologiczną [19]. Określenie korelacji między polimorfizmem pojedynczego nukleotydu, obniżoną aktywnością cytochromu P450 2D6 a leczeniem tamoksifenem pozwoliło na przykład na lepszą weryfikację pacjentów i wyeliminowanie leczenia raka piersi tamoksifenem u tych chorych, u których leczenie to jest nieefektywne [20].

Należy również wspomnieć, że idea data-miningu w onkologii nie może być ograniczona tylko do eksploracji danych z SIM czy EHR. Innym przykładem drążenia danych poza EHR i SIM jest text-mining bibliograficznych baz danych. W badaniach przeprowadzonych przez Tiffin i wsp. [16] przy użyciu technik data-i text-miningu w bazach danych PubMed i Ensembl wyodrębniono spośród 417 genów potencjalne geny związane z takimi chorobami, jak: rak piersi, stercza, nerwiak czy glejak siatkówki.

Niezmiernie ciekawym rozwiązaniem jest projekt hurtowni danych tranSMART, który jest platformą gromadzącą informacje z wielu obszarów medycyny. Hurtownia danych zbiera dane między innymi z przedklinicznych i klinicznych badań nad chorobami nowotworowymi, dane ekspresji genów i białek, dane metaboliczne, morfologiczne. System może być przydatny do usystematyzowania informacji na temat fenotypu/genotypu, a także do lepszego projektowania badań klinicznych czy też przyporządkowania subtypów molekularnych do poszczególnych chorób. Głębsze zrozumienie złożonych procesów biologicznych może się przyczynić do stworzenia efektywniejszych rodzajów terapii [21].

\section{Zastosowania informacji genetycznej, epigenetycznej, transkryptomiki i proteomiki w medycynie personalizowanej}

Medycyna personalizowana zdecydowanie eliminuje model, w którym takie samo leczenie pasuje do wszystkich pacjentów z danym nowotworem (one-size fits all model). Nowe podejście skupia się na molekularnej, a w szczególności genetycznej informacji o pacjencie.
Idea, aby użyć informacji genetycznych pacjenta do zindywidualizowanej diagnozy i leczenia, nie jest nowa sama w sobie. W chwili obecnej istnieje wiele przykładów, w których testy genetyczne są podstawą profilaktyki, diagnostyki i indywidualnej terapii, np. praktyczne zastosowanie wykrywania mutacji w genach BRCA1 i BRCA2, APC, CHEK2, NBS1.

W medycynie personalizowanej najczęściej spotyka się koncepcję dotyczącą terapii celowanej (targeted therapies) i docelowego, indywidualnego dozowania leków (targeted dosing). Przykładem jest terapia z wykorzystaniem trastuzumabu z Her2-dodatnim receptorem u pacjentów z rakiem piersi. Obecnie określa się nadekspresję białka Her2, ponieważ pacjentka z Her2-dodatnim receptorem raka piersi nie odpowiada dobrze na standardowe terapie [22]. Ponieważ wieloletnie badania korelacji pomiędzy nadekspresją HER2 a hormonoterapią wykazały oporność na tę terapię [23], dalsze poszukiwania odpowiedniego leczenia zaowocowały pozytywną odpowiedzią pacjentów na lapatinib i dożylne przeciwciało monoklonalne - trastuzumab (herceptin) [24]. Drugim przykładem terapii docelowej jest terapia z wykorzystaniem erlotinibu, który jest inhibitorem kinazy tyrozynowej receptora dla naskórkowego czynnika wzrostu (epidermal growth factor - EGFR) i silnie hamuje wewnątrzkomórkową fosforylację EGFR. W przypadku leczenia erlotinibem u pacjentów, którzy nigdy nie palili i mają dodatni status EGFR, rokowanie jest dużo lepsze niż u pacjentów z ujemnym statusem EGFR.

Innym przykładem indywidualnego dozowania leków w medycynie personalizowanej jest chemioterapia z wykorzystaniem 6-merkapto-puryny (6-MP). Odpowiednia ordynacja 6-PM przy leczeniu ostrej białaczki limfoblastycznej powinna być oparta na genotypie pacjenta, z uwzględnieniem genetycznego polimorfizmu w genie S-metylotransferazy tiopuryny (thiopurine S-methyltransferase). Obniżenie aktywności enzymu TPMT jest związane z polimorfizmem w genie TPMT, co w konsekwencji przejawia się zwiększoną toksycznością leczenia [25].

Tradycyjna radioterapia często związana była z koncepcją dozowania ,jedna, ta sama dawka dla wszystkich pacjentów z danym nowotworem” (,one size fits all” concept of dosing). Takie leczenie oczywiście często było modyfikowane a priori w związku z charakterystyką pacjenta (np. stan ogólny chorego) czy a posteriori - bazując na odpowiedzi pacjenta na prowadzone leczenie [25].

W nowoczesnej radioterapii wiedza o ekspresji poszczególnych genów staje się przydatna i stosowana w praktyce klinicznej. Wstępne badania nad ekspresją genów na liniach komórkowych nowotworu stercza [26] wskazują, że niska ekspresja genu DAB2IP jest związana ze zwiększoną opornością na promieniowanie jonizujące. Ta zwiększona oporność w komórkach nowotworowych pozbawionych ekspresji genu DAB2IP jest głównie związana z szybszą naprawą kinetycznych uszkodzeń obu nici DNA (double-strand breaks DSB). Te wstępne badania są na tyle obiecujące, że identyfikacja pacjenta z niską ekspresją genu DAB2IP może być pomocna przy wyborze alternatywnej metody leczenia.

Innym przykładem klinicznego zastosowania informacji genetycznej jest skojarzone leczenie radiochemioterapią 


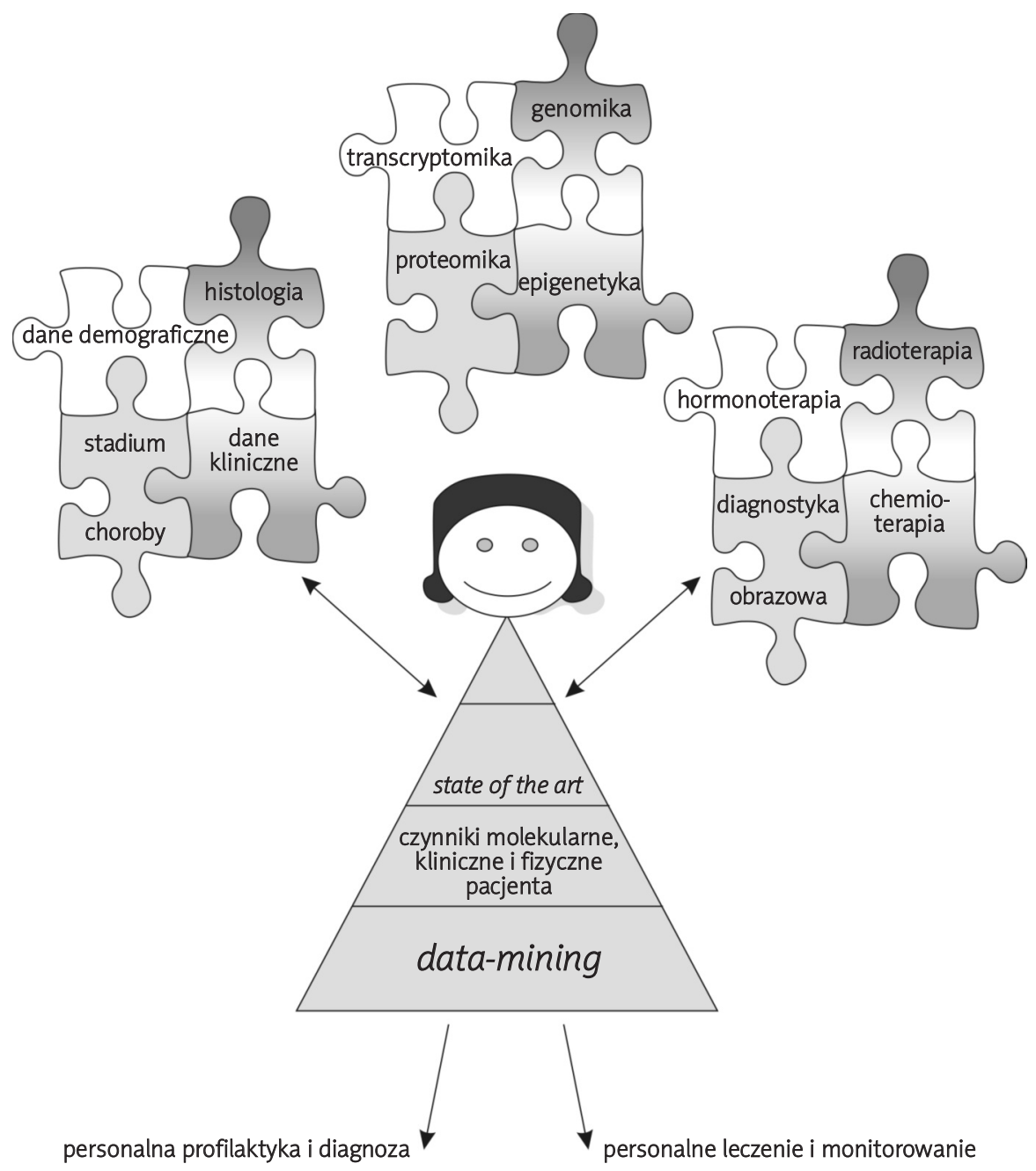

Ryc. 1. Schemat data-miningu w medycynie personalizowanej. Górny panel: puzzle przedstawiają zbiory informacji i przykłady korelacji między poszczególnymi czynnikami/zbiorami. Środkowy panel: eksploracja informacji z publikacji, danych szpitala oraz Systemu Informacji Medycznej (SIM) czy Elektronicznego Rekordu Pacjenta (Electronic Health Record - EHR). Dolny panel: informacja dla lekarza jako wynik eksploracji danych

Fig. 1. Data-mining in personalized medicine. Top panel: the puzzles represent information sets and examples of correlations between particular factors/sets. Middle panel: data-mining of published information, hospital data and Medical Information System (SIM) or Electronic Health Record (EHR). Bottom panel: information for physician, obtained through data-mining

temozolomidem pacjentów z glejakiem wielopostaciowym, które pozwala zwiększyć prawdopodobieństwo 2-letniego przeżycia u chorych z hipermetylacją promotora genu odpowiedzialnego za syntezę enzymu naprawczego MGMT (06-methyl-guanine-DNA-methyltransferase) [27, 28].

Projektowanie nowoczesnego, indywidualnego leczenia dla konkretnego pacjenta w radioterapii mogłoby się opierać na wykorzystaniu nowych technologii informatycznych i analizie danych data-miningu, genetycznych, klinicznych, fizycznych czy text-miningu zebranych również z publikacji dotyczących radioterapii.

Nie tylko genomika i transkryptomika rozkwita w medycynie personalizowanej. Również dzięki proteomice zmieniła się diagnoza i leczenie niedrobnokomórkowego raka płuca (NSCLC), w którego leczeniu skuteczność chemioterapii wynosiła poniżej 30\%. Taguchi i wsp. wykazali przejrzystą klasyfikację pacjentów z NSCLC z dobrymi i słabymi wynikami leczenia inhibitorem kinazy tyrozynowej recep- tora dla naskórkowego czynnika wzrostu (tyrosine kinase inhibitors-TKI-treatment-EGFR). Dlatego też ten algorytm może wspomagać wstępną selekcję stosownej subgrupy pacjentów z NSCLC do leczenia z użyciem EGFR-TKI [29].

Epigenom jest definiowany jako system regulujący ekspresje genu, znajdujący się poza DNA [30]. Przykładową zmianą w ekspresji genów, która bezpośrednio nie ma wpływu na sekwencje DNA, jest metylacja DNA. Zastosowanie epigenetyki w medycynie personalizowanej bazuje na badaniach hipometylacji i hipermetylacji w komórkach nowotworowych [31]. Hipometylacja genomowego DNA prowadzi do niestabilności genetycznej. Podobnie nieprawidłowa hipermetylacja promotorów prowadzi do dezaktywacji genów supresorowych. Przykładem zastosowania epigenetyki w medycynie personalizowanej jest metylacja promotora TP16 w ślinie palaczy, która może być zidentyfikowana do 3 lat wcześniej niż rozpoznanie raka płaskonabłonkowego (squamous cell carcinoma) w diagnostyce klinicznej [32]. 


\section{Populacja komórek nowotworowych}

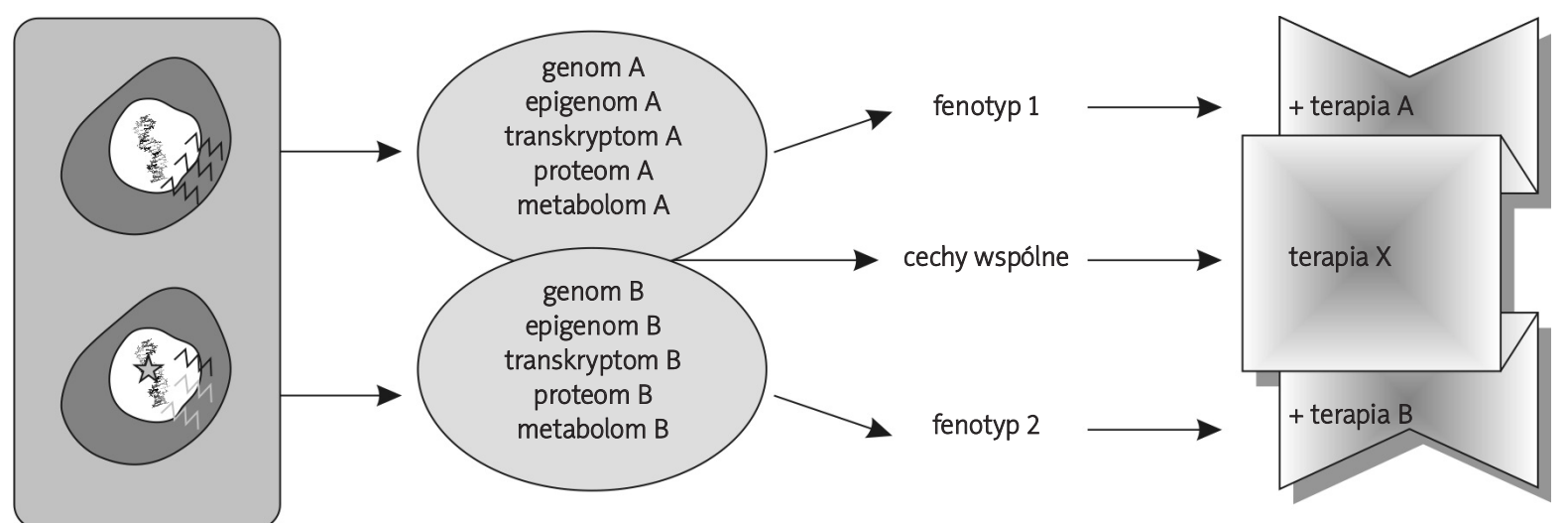

Ryc. 2. Przyszłość medycyny personalizowanej: wizja czy prawdziwy scenariusz? Populacja komórek nowotworowych zostanie określona pod względem genetycznym, epigenetycznym, transkrypcji oraz translacji, metabolitów, struktury i funkcji białek. Data-mining określi fenotyp oraz cechy wspólne wszystkich badanych komórek nowotworowych danego chorego. Następnie data-mining wykorzysta wszystkie dane do stworzenia terapii „uszytej na miarę” pacjenta: na podstawie dodatkowych danych klinicznych podpowie terapię X, która może być dodatkowo uzupełniona terapią A lub terapią B. Rycina zaadaptowana z artykułu [18]

Fig. 2. Future of personalized medicine: vision or realistic scenario? Many neoplastic cells are determined in terms of genetic, epigenetic, transcriptional and translational properties, as well as the structure and function of the proteins and metabolites. Data-mining will specify the phenotype and common characteristics of all neoplastic cells in the patient. Afterwards, the data-mining will use all the data to develop a tailored therapy for the patient: on the basis of additional clinical information it will suggest therapy X, which may be supplemented with therapy $A$ or B. Figure adapted from [18]

Metylacja promotora genu TP16 została zaproponowana jako marker wczesnego wykrywania raka płuc i również w przesiewowych badaniach profilaktycznych [33].

Należy jednak pamiętać, że opisywanie medycyny personalizowanej tylko i wyłącznie jako terapii celowanej czy terapii z indywidualnym dawkowaniem leku, jest zbytnim uproszczeniem. Wszechstronna wiedza dotycząca genomu, epigenomu, transkryptomu, proteomu i metabolizmu pacjenta, ułatwi lekarzom zindywidualizowaną profilaktykę, diagnostykę, leczenie oraz monitorowanie choroby (ryc. 1.).

\section{Podsumowanie}

Nowe technologie, jakimi są: data-mining i techniki „wysoko wydajnych technologii” gromadzenia danych, otwierają drzwi w kierunku medycyny personalizowanej, pozwalając na diagnozę oraz planowanie leczenia na poziomie molekularnym, specyficznym dla każdego chorego. Wysoko wydajne technologie są doskonałym źródłem informacji do personalizowanej medycyny. Dlatego też istnieje potrzeba współpracy między onkologami, radiologami, genetykami, biologami molekularnymi, biotechnologami, farmakologami, patomorfologami i bioinformatykami oraz specjalistami od data-miningu, aby zawęzić grupę badaną, wykonać badania z wykorzystaniem wysoko wydajnych technologii razem z bioinformatyczną analizą danych, wyszukać korelacje, wykorzystując data-mining i wprowadzić badania do diagnostyki lub postępowania klinicznego bądź wyznaczyć kierunki dalszych badań klinicznych.

Preferowana infrastruktura w medycynie personalizowanej pozwalałaby lekarzowi na łatwy dostęp do komplet- nych danych pacjenta, zawierających informacje kliniczne, fizyczne i molekularne, jak również notatek lekarzy z obserwacji klinicznych. Dzięki dobrej elektronicznej bazie danych, eksploracja danych pacjenta i porównanie tych wyników z aktualnym stanem wiedzy pozwoli na określenie nowych korelacji w celu zindywidualizowanej diagnozy, leczenia i lepszego monitorowania choroby (ryc. 1.). Idealnym rozwiązaniem w onkologii byłoby pobranie materiału komórkowego od pacjenta i określenie profilu molekularnego dla różnych populacji komórek nowotworowych (ryc. 2.).

Dysponując informacjami o wspólnych cechach z poszczególnych genomów, epigenomów, transkryptomów, proteomów i metabolizmu, można by stworzyć, przy użyciu metod drążenia danych (data-mining), najlepsze, indywidualne leczenie, które w zależności od fenotypu pacjenta oraz jego danych fizycznych, klinicznych i demograficznych, można by uzupełnić czy dodatkowo zmodyfikować, również korzystając z metod data-miningu (ryc. 2.).

Czy to jest wizja czy prawdziwy scenariusz? Wydaje się możliwe, aby w niedalekiej przyszłości, lekarz klinicysta ordynował pacjentom leczenie, bazując na unikanej informacji molekularnej i data-miningu.

\section{Piśmiennictwo}

1. PMC, The Case for Personalized Medicine. Personalized Medicine Coalition 2009

2. Spear BB, Heath-Chiozzi M, Huff J. Clinical application of pharmacogenetics. Trends Mol Med 2001; 7: 201-4.

3. Lavrac N. Selected techniques for data mining in medicine. Artif Intell Med 1999: 16: 3-23. 
4. Mullins IM, Siadaty MS, Lyman J, et al. Data mining and clinical data repositories: Insights from a 667,000 patient data set. Comput Biol Med 2006; 36: 1351-77.

5. Schwarzer G, Vach W, Schumacher M. On the misuses of artificial neural networks for prognostic and diagnostic classification in oncology. Stat Med 2000; 19: 541-61.

6. AHA, Continued Progress Hospital Use of Information Technology. American Hospital Association 2007.

7. Hoerbst A, Ammenwerth E. Quality and certification of electronic health records - An overview of current approaches from the US and Europe. Applied Clinical Informatics 2010; 1: 149-64.

8. EuroRec, Articles of Association. European Institute for Health Records 2009.

9. Madis T, Ross P. Patient Opportunities in the Estonian Electronic Health Record System. Medical and Care Compunetics, ed. Bos L, et al. 2010; 156: 171-7.

10. Greenhalgh T, Stramer K, Bratan T, Byrne E, Russell J, Potts HW. Adoption and non-adoption of a shared electronic summary record in England: a mixed-method case study. BMJ 2010; 340: doi: 10.1136/bmj.c3111.

11. Nyczaj K. Czy marzenia o internetowym koncie pacjenta się spełnią? Nowoczesna Klinika 2010. dostępne na: http://nowoczesna-klinika.pl/pl/artykuly/17/Analizy_Raporty/1/292/Czy_marzenia_o_internetowym_koncie_pacjenta_sie_spelnia

12. MZ, Strategia e-Zdrowie Polska 2009-2015. Ministerstwo Zdrowia 2009.

13. Li L, Tang H, Wu Z, Gong J, Gruidl M, Zou J, Tockman M, Clark RA. Data mining techniques for cancer detection using serum proteomic profiling. Artif Intell Med 2004; 32: 71-83.

14. Lisboa PJ, et al. Data mining in cancer research. IEEE computational intelligence magazine 2010; 5: 14-18.

15. Goldstein DB. 2020 visions: Personalized medicine. Nature 2010; 463: 26-32.

16. Tiffin N, Kelso JF, Powell AR, Pan H, Bajic VB, Hide WA. Integration of text and data-mining using ontologies successfully selects disease gene candidates. Nucleic Acids Res 2005; 33: 1544-52.

17. Gundem G, Perez-Llamas C, Jene-Sanz A, Kedzierska A, Islam A, DeuPons J, Furney SJ, Lopez-Bigas N. IntOGen: integration and data min ing of multidimensional oncogenomic data. Nat Methods 2010; 7 : 92-3.

18. van der Brug MP, Wahlestedt C. Navigating genomic maps of cancer cells. Nat Biotechnol 2010; 28: 241-2.

19. Phillips KA, Veenstra DL, Oren E, Lee JK, Sadee W. Potential role of pharmacogenomics in reducing adverse drug reactions: a systematic review. JAMA 2001; 286: 2270-9.

20. Hoskins JM, Carey LA, McLeod HL. CYP2D6 and tamoxifen: DNA matters in breast cancer. Nat Rev Cancer 2009; 9: 576-86.

21. Szalma S, Koka V, Khasanova T, Perakslis ED. Effective knowledge management in translational medicine. J Transl Med 2010; 8: 68.

22. Ménard S, Pupa SM, Campiglio M, Tagliabue E. Biologic and therapeutic role of HER2 in cancer. Oncogene 2003; 22: 6570-8.

23. De Laurentiis M, Arpino G, Massarelli E, et al. A meta-analysis on the interaction between HER-2 expression and response to endocrine treatment in advanced breast cancer. Clin Cancer Res 2005; 11: 4741-8.

24. Demonty G, Bernard-Marty C, Puglisi F, Mancini I, Piccart M. Progress and new standards of care in the management of HER-2 positive breast cancer. Eur J Cancer 2007; 43: 497-509.

25. Lesko LJ. Personalized medicine: elusive dream or imminent reality? Clin Pharmacol Ther 2007; 81: 807-16.

26. Kong Z, Xie D, Boike T, et al. Downregulation of human DAB2IP gene expression in prostate cancer cells results in resistance to ionizing radiation. Cancer Res 2010; 70: 2829-39.

27. Hegi ME, Diserens AC, Gorlia T, et al. MGMT gene silencing and benefit from temozolomide in glioblastoma. N Engl J Med 2005; 352: 997-1003.

28. Weller M, Stupp R, Reifenberger G, Brandes AA, van den Bent MJ, Wick W, Hegi ME. MGMT promoter methylation in malignant gliomas: ready for personalized medicine? Nat Rev Neurol 2010; 6: 39-51.

29. Taguchi F, Solomon B, Gregorc V, et al. Mass spectrometry to classify non-small-cell lung cancer patients for clinical outcome after treatment with epidermal growth factor receptor tyrosine kinase inhibitors: a multicohort cross-institutional study. J Natl Cancer Inst 2007; 99: 838-46.

30. Jones PA, Martienssen R. A blueprint for a Human Epigenome Project: the AACR Human Epigenome Workshop. Cancer Res 2005; 65 : 11241-6.

31. Cheung HH, Lee TL, Davis AJ, Taft DH, Rennert OM, Chan WY. Genome-wide DNA methylation profiling reveals novel epigenetically regulated genes and non-coding RNAs in human testicular cancer. Br J Cancer 2010; 102: 419-27.

32. Palmisano WA, Divine KK, Saccomanno G, Gilliland FD, Baylin SB, Herman JG, Belinsky SA. Predicting lung cancer by detecting aberrant promoter methylation in sputum. Cancer Res 2000; 60: 5954-8.

33. Belinsky SA, Nikula KJ, Palmisano WA, Michels R, Saccomanno G, Gabrielson E, Baylin SB, Herman JG. Aberrant methylation of p16(INK4a) is an early event in lung cancer and a potential biomarker for early diagnosis. Proc Natl Acad Sci U S A 1998; 95: 11891-6.

\section{Adres do korespondencji}

Remigiusz Lewandowski, PhD

Katedra Informatyki w Zarządzaniu

Uniwersytet Technologiczno-Przyrodniczy

im. J. i J. Śniadeckich w Bydgoszczy

ul. prof. S. Kaliskiego 7 bud. 3.1

85-796 Bydgoszcz

e-mail: lewandowski@mailplus.pl 